Western University

Scholarship@Western

Aboriginal Policy Research Consortium International (APRCi)

6-2007

\title{
An Indigenous Perspective on National Parks and Sami Reindeer Management in Norway
}

Jan Åge Riseth

Follow this and additional works at: https://ir.lib.uwo.ca/aprci

Part of the Nature and Society Relations Commons

Citation of this paper:

Riseth, Jan Åge, "An Indigenous Perspective on National Parks and Sámi Reindeer Management in Norway" (2007). Aboriginal Policy Research Consortium International (APRCi). 220.

https://ir.lib.uwo.ca/aprci/220 


\title{
An Indigenous Perspective on National Parks and Sámi Reindeer Management in Norway
}

\author{
JAN ÅGE RISETH \\ Norut Social Science Research Limited and Nordic Sámi Institute, P.O. Box 250, \\ N-8504 Narvik, Norway. \\ Email:janar@samf.norut.no
}

Received 3 October 2006; Revised 29 January 2007; Accepted 31 January 2007

\begin{abstract}
Protection of nature for biodiversity, and for the material livelihoods of Indigenous peoples, have much in common. Indigenous relations to nature are, however, based on unity between use and protection, implying that human use is necessary for effective protection. Often protected areas include the homelands of Indigenous peoples, whose needs and rights are still being ignored to a large extent. This paper explores the effects of a plan for a significant increase of large nature protection areas in Norway, still under implementation. Most of the new protection areas are in the heartland of the Indigenous Sámi, whose core livelihood is reindeer management. The plan implies transfer of jurisdiction from Indigenous and local domains to formalised central domains. In several cases, this has provoked Indigenous and rural groups to organised resistance. In this case study, there are signs of new tensions between Sámi and other rural groups. Indigenous land use can be marginalised by park restrictions and increasing pressure from visitor activity. The Sámi response was to boycott the park management board leading to a stalemate. A robust solution seems to require consideration of deeper institutional levels.
\end{abstract}

KEY WORDS National Parks; Indigenous peoples; conservation; Sámi reindeer management; institutional level analysis

\section{Introduction}

Protection of nature for biodiversity, and the material livelihoods of Indigenous peoples, have much in common. Indigenous relations to nature are, however, based on unity between use and protection, implying that human use is necessary for effective protection. In contrast to this, the western tradition of protection of natural areas, based on statutary law, goes back to the United States of America and the establishment of the Yellowstone National Park in 1872. The ethos of Yellowstone has been influential in every corner of the globe and has strong positive and negative influences: millions of tourists and city dwellers have enjoyed the Yellowstone outdoors; Shoshone, Bannock and Crow were made outlaws in their own Yellowstone lands (Jacoby, 2001, 81-146). In the decades since 1872, the Yellowstone model has been replicated across the globe: habitats, landforms and native flora and fauna have been valued and preserved but nature and culture have been separated. Tourists are encouraged to enjoy national parks as visitors: Indigenous peoples are marginalised and dispossessed and their role as resource managers devalued or rendered invisible (Poirier and Ostergren, 2002, 333-335).

The Yellowstone model has had serious repercussions, far beyond the United States; areas selected for national parks tend to be residual lands of minor economic interest for other uses, and make non-sustainable use of other vulnerable 
areas more acceptable. Often protected areas include the homelands of Indigenous peoples, their needs and rights to a large extent being ignored (IUCN, 1994; Stevens, 1997). Contemporary conflicts between preservation/conservation and livelihoods are well documented. Neuman (1998) and Hitchcock (2002) are among those who set out the contestations between parks and peoples in the forests, grasslands and deserts of Africa. Poirier and Ostergren (2002) have compared the experiences of Indigenous peoples as parks and protected natural areas were set up in Australia, Russia and the United States. Fearnside (2003) and Smarden and Faust (2006) unravel the conflicts between Indigenous peoples and biosphere reserves in Brazil and Mexico. Nicholas (2005) identifies similar problems in Malaysia. Chatty (1998) reports on enclosures designed to conserve wildlife and exclude pastoralists in the Middle East.

West and Brechin (1991) in an edited volume entitled Resident Peoples and National Parks identify the ecological imperatives and the ethical ambiguities associated with the preservation of representative ecosystems. The case studies presented in Resident Peoples, drawn from around the world, show that parks and peoples are not incompatible and that ecological goals are not put at risk when Indigenous peoples and traditional ecological knowledge are included in park management. A decade later a special issue of Ecology and Society on the theme 'traditional knowledge in social-ecological systems' (Folke, 2004) and books by Adams and Mulligan (2003) on Decolonising Nature and by Berkes et al., (2003) on Navigating Social-ecological Systems are markers of the extent to which past and present injustices have been clarified and new relationships are emerging. In a 2006 media release by the Zoological Society of London, intent on the preservation of African wildlife, urged a shift away from 'fortress nature reserves' to shared access and shared responsibility to protect rangelands and wildlife (Zoological Society of London, Press Release, 12 January, 2006).

Norway, along with its neighbours Sweden and Finland, has taken up the Yellowstone model (Adams, 2005; Lasko, 2005; Mazzullo, 2005). Norway established its first national park in 1962. A national plan for the first generation of national parks was drawn up in 1964 and 15 national parks were established by 1981. Ten of these parks are within the Norwegian part of Sapmi (Sámiland or the home of the Sámi). Figure 1 shows the national parks of Norway's mainland, and timespans for the adoption and extension of parks on both sides of the line delineating the Sámi reindeer management area.

During the last three decades of the twentieth century, important international advances were taken both in policies for protection of the environment and in the recognition of Indigenous peoples' rights. Norway strongly supported the former at the World Commission on Environment and Development (WCED, 1987) and the latter when the ILO Convention on Indigenous and Tribal Peoples was adopted by the International Labour Conference in 1989. Within Norway, political activism for the advancement of nature conservation and Indigenous issues remarkably merged in the struggle to stop the damming of the Alta-Kautokeino River from the late 1970s. Although the river was dammed, broad support for Sámi claims promoted a major shift in governmental Indigenous policy (Minde, 2005) with important outcomes such as the establishment of the Sámi Parliament in 1989 and the Finnmark Land Reform implemented in 2006. The ILO Convention on Indigenous and Tribal Peoples and the Dana Declaration on Mobile Peoples and Conservation are prominent examples of documents which establish new international standards for policy-making.

On 26 June, 2006 the solemn opening of two new National Parks, in the presence of Her Royal Highness Crown Princess Mette Marit, took place in Lierne Municipality, Nord-Trøndelag County in Mid-Norway. The park areas are in the heartland of the Indigenous reindeer managing areas of South Sámi. Remarkably, the Indigenous hosts did not take part in the ceremony - they boycotted the park opening - and since then they have boycotted participation in the park board. This article explores the reasons for the confrontation and asks if it is a local standoff or part of a wider pattern?

\section{Nature protections, Indigenous and local rights}

The 1980s was the decade when Sámi in Norway brought Indigenous issues onto the national political agenda. The Sámi Parliament was set up in 1989 but concerns related to land rights lagged behind. Not until 2006 were the Finnmark land reforms set in place. Government found cultural issues less problematic than land rights. Nature protection is even more complex.

A comprehensive plan for national parks was published in 1966 and the Nature Protection Act was passed in 1970. The Ministry of 


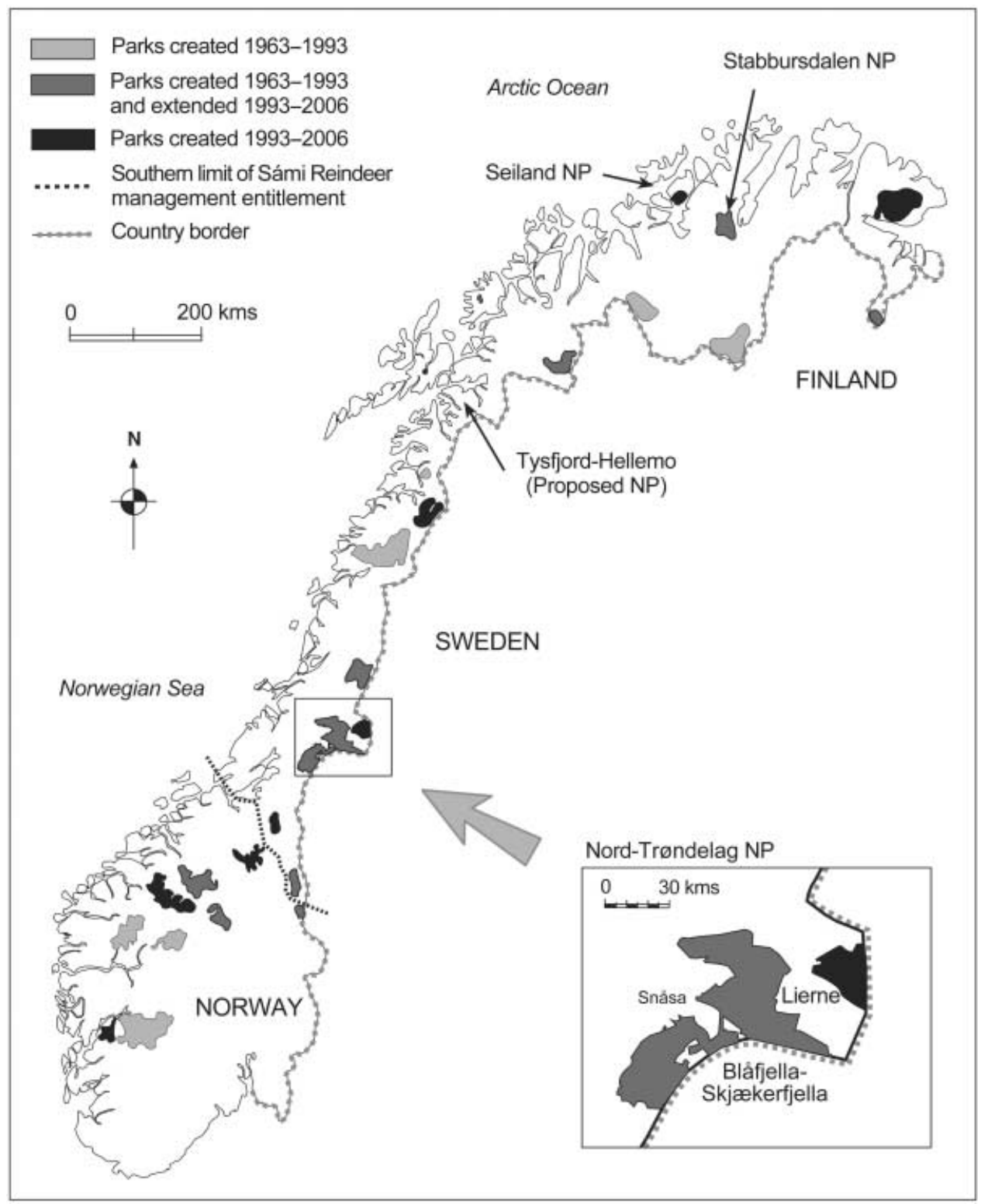

Figure 1 National parks on the Norwegian mainland. Timespans for adoption and extension. Inset: Detail of national parks established in Snåsa and Lierne, Nord-Trøndelag.

Environment was established in 1972 and county level environmental departments a decade later. These agencies established strong links with user groups and environmental NGOs (Skjeggedal et al., 2004). Not long after, Sámi reindeer management was recognised through a General Agreement for the Reindeer Industry (1976) and the Reindeer Management Act (1978). The Directorate for Reindeer Management was set up as the core governmental body in 1979. The scene was set for a policy confrontation between recognition of Indigenous rights and the creation of new forms of nature protection. When the Sámi Parliament was opened in 1989, the nature protection regime was already established as a nexus of power, intent on expanding into the outfields of the Norwegian reindeer herders. Plans for a new round of national parks were formulated (NOU 1986; St. meld., 1991-1992). Parliament gave approval in 1993 and gave the mandate for implementation to the Directorate of Nature Management and regional environmental 
authorities. Nature protection policies were firmly in place: the longstanding and recently confirmed rights of Indigenous and local people were under threat.

\section{Indigenous land rights}

The colonisation of Sapmi has been a long historical process accentuated by the separation of Norway and Sweden and the creation of an international border which made life difficult for migratory herders (Zachrisson, 1994; Hansen and Olsen, 2004; Riseth, 2005). Colonisation continued, and was followed by assimilation policies oppressing Sámi culture and language, and demanding fluency in Norwegian language in order to acquire land title. Decolonising efforts from the 1970s onwards have been uneven in Norway: Sámi language and culture are now recognised, but Norway, in contrast to countries such as Canada, Australia and New Zealand, has been slow to identify and restore Indigenous land rights (Pawson and Cant, 1992; Baker et al., 2001; Bull, 2003). Important breakthroughs for Sámi reindeer herders came in Supreme Court verdicts from 1968 onwards and the recognition of reindeer management as an industry (Riseth, 2005). Currently reindeer herding Sámi have usufructuary rights close to those of full co-owners and are protected by international law (Bull, 2004). The reality is that reindeer herders face comprehensive competing land use pressures including transport and hydro electric development, and recreational uses by urban people.

The Finnmark Land Reform in 2006 is the first material outcome of the works of the Sámi Rights Commission appointed in 1980 (NOU, 1984). These claims have been settled, and the Commission is now considering the Sámi claims further south. It is at this point that the land claims process and the creation of new national parks collide. The slowness of the land claims process means that the resolution of claims can be pre-empted by the creation of new parks in areas such as Blåfjella-Skjækerfjella and Lierne.

\section{Property rights and outfield land use}

The essence of property rights to land is not the possession of a physical piece of land per se, but the right to live off the land (Soupajärvi, 2003) and enjoy the benefit stream it provides (Vatn, 2005). Norway has a long history of property rights characterised by a mix of private and common rights. Private farmers are also coowners of outfields, where benefits are divided between owners: for example, one might hold rights to pasture, a second to the wood, a third to the hydropower of the stream while all hold fishing rights in common (Sevatdal, 1998). Though the outfields in question are Crown lands, there are different kinds of commons with time-honoured traditions of split property rights. State commons (statsalmenning) are dominant from MidNorway (Trøndelag) southwards; the State is the holder of title, but the management and monitoring are conducted at municipal level by boards representing the holders of rights (fjellstyret). The balance between Sámi reindeer herders and other land users is negotiated within the framework of the Planning and Building Act 1985 (PBA) which has strict rules for changes of established land use. The municipalities of Snåsa and Lierne have comprehensive land use plans which regulate the outfields. The plans have worked well for Sámi and non-Sámi alike: conflicts are mediated locally and all see themselves as responsible owners and users who conserve the environment under the PBA framework.

\section{A shift in domain control}

The nature protection regime shifts the protection of biodiversity away from conservation by responsible users. The creation of parks such as Blåfjella-Skjækerfjella and Lierne transfers jurisdiction from local domain control to central domain control. Nature protection is given priority over traditional uses.

There are three dimensions of this domain control which are inappropriate from a Sámi perspective. Firstly, under the present regime, Sámi are able to interact with their non-Sámi neighbours and achieve outcomes which are mutually beneficial, which keep the migration paths open, and which protect summer pastures and winter forests. Under a national park regime, the locus of power moves from the local community to a regional or central bureaucracy intent on nature protection.

Secondly, there are land rights perspectives relating to new resources not yet discovered and to existing resources which may be used in new ways. Berge (2006) defines these rights as 'the remainder' and spells out the implications of domain transfer. Sámi, along with other current owners or co-owners of the lands in question, have a floating system of rights and uses, acknowledged but not currently defined. The creation of a national park will curtail their existing rights by unilaterally defining them. It will, in effect, remove 'the remainder' from the property rights of Sámi reindeer herders. 
Thirdly, there is the traditional ecological knowledge (TEK) of the Sámi reindeer herders, accumulated through generations of close contact with nature. Sámi herders continuously monitor subtle environmental changes and adjust their herding strategies accordingly (Helander and Mustonen, 2004). Survival depends on this. Traditional ecological knowledge however, has no assured place in the new protection regime.

These three dimensions aside, there are issues of justice still to be addressed. Moen (1998) points out a remarkable paradox between which nature types are threatened and which areas become protected. Those portions of the Norwegian environment under greatest pressure are the areas where the majority of urban dwellers live; those which are the best preserved are the boreal and the alpine zones essential for Sámi reindeer herding. While less than $2 \%$ of former are protected, $6 \%$ of the north boreal and $14 \%$ of the alpine zones are to be protected, that is, the less the urban pressure on the nature type, the higher the propensity for protection. The government, it seems, is intent on increasing the percentage of protected areas and is prioritising protection in the areas where this is easiest to implement. Why, asks Berge (2006, 65), should people support the 'modern, largely an urban-initiated concern with environmental protection' when there are no obvious threats towards the land. What, Sámi ask, should the land be protected from? We have taken good care of it for centuries. Such protection, can be seen as an attack on rural and Indigenous rights and freedom of action. These questions, raised by Sámi, have been echoed by other Indigenous peoples across the globe. The international community is now responding.

\section{Which protection?}

The International Union for the Conservation of Nature and Natural Resources (IUCN) responded to these concerns. During the decade 19841994, it reviewed its Guidelines for Protected Area Management Categories to include the interests of Indigenous people. The guidelines separated the ownership of land and resources from the requirements and objectives of management by extending the range of protection categories (Stolton and Oviedo, 2004).

Norway participated in IUCN while the new policies were formulated but made uneven efforts to incorporate these into its domestic policies. Undisturbed natural landscapes are prioritised in National Park Plan 2 without acknowledgement that these are long-used Sámi cultural landscapes, and that many of the areas selected for parks are core areas for Sámi reindeer herding and constitute the heartland of Sapmi. Cultural heritage monuments receive explicit recognition but there is little focus on contemporary Sámi reindeer management (NOU, 1986; St. meld., 1991-1992). From a Sámi perspective, heritage remains are given priority over living culture and landscape.

A survey of Sámi experience with national parks Government ambitions for the expansion of national parks have been fulfilled (Figure 1). At New Year 2007, 18 of 29 national parks on the Norwegian mainland were established within current Sapmi. Total national park area within Norwegian Sapmi has increased three and a half times, but not without protests. Proposals for the extension of the Stabbursdalen National Park in Finnmark were adopted in the face of strong local concerns and the objections of the Sámi Parliament. In December 2006 Seiland National Park was established despite protests from the regional Reindeer Management Board asserting a breach of Indigenous international law. Only at Tysfjord/Hellemo has a protection initiative been stopped as a result of Sámi protest (NOU, 2004).

A survey of the experience of Sámi in reindeer herding districts, where national parks have been set up, shows very diverse results. Generally, most herders hold that protection by park status helps to safeguard their lands and the reindeer migration paths from heavier encroachments such as public utilities or private holiday homes. Simultaneously, herders point to negative experiences relating to park management and an increase in the burden of predators such as lynx and wolverine. Most herders consider that opportunities for commercial tourism and recreation in national parks are a threat to reindeer herding since they disturb grazing, rutting, and calving, and disrupt the seasonal migrations (Jystad, 2007). Districts having a park in their winter area report that the advantages outweigh the drawbacks, while most of the other districts find balancing difficult; of the remainder, more are negative than positive.

Blåfjella-Skjakerfjella and Lierne national parks Blåfjella-Skjækerfjella and Lierne national parks, proposed under the National Park Plan 2 process and the subject of the June 2006 boycotts, with connected smaller protection areas include $2400 \mathrm{~km}^{2}$ of mountain and forest areas in the inland parts of Nord-Trøndelag County (Figure 1, inset). The area is important for reindeer herding, 
sheep pasturing, hunting, and recreation activities by people in the region. Those most affected by the proposals were the reindeer herding South Sámi and the rural residents of the municipalities of Snåsa and Lierne.

The County Governor of Nord Trøndelag was charged with implementing the proposal in 1993. His Department of Environment prepared the draft protection plan in 1994, and arranged information meetings with the local community in 1995-96 (NTCC, 2001). Sámi were initially positive towards the proposal: as reindeer herders they saw the advantage of protecting their land from large encroachments, including forest truck roads and vacation cottage areas, and the possibility of protecting forest areas which are important for winter pastures. In 1998 municipalities constituted a nature management board, in order to co-ordinate their relations with the protection authorities (NTCC, 2001).

However, the rural population, Sámi and nonSámi, were provoked by the top down running of the implementation process: it was seen as a take-over by the nature protection regime. Some $92 \%$ of the population in the municipality of Snåsa signed an appeal '[f] ]or a National Park [based] on the Values of the People' calling for greater local control. The proposal was modified by reducing the size of the parks and excluding two mountain farms. The government also prepared an experiment of local management with divided authority between the county environmental department, the municipalities and the regional reindeer management office. This was a policy response to the rural critique. The Sámi, however, still felt disadvantaged by the management arrangements:

The reindeer keepers point out that they are the ones who have had total control over these areas both in terms of use as well as in terms of preservation. It is a paradox for the reindeer keepers that the issues that created the basis for the claim for preservation, such as forestry roads, development of cottage areas and the like, are kept outside the park, that the protection even creates new demands for the development of cottages and that this is in fact used as a sales argument for the park (NTCC, 2001, 43).

Sámi were uncomfortable with the magnitude of planned activity within and around the park: instead of providing them with protection, the new national parks would mean increased pressure on their reindeer herding areas. Their response included the withdrawal of their two representatives on the provisional management board for Blåfjella-Skjækerfjella National Park (17 representatives on the board). They were unwilling to be outnumbered by a range of NGOs and municipalities and feared that that they would have no real management influence. A later offer to increase their representation to four on the board has not changed their opinion (Jystad, 2006).

As of April 2007, the management deadlock continues. The government is embarrassed by the boycott, and there are signs of tension between the Sámi and other rural groups. The ability of Sámi and non-Sámi to work together in municipal government has been weakened by the conflicts surrounding the park.

\section{Theoretical issues}

Nature conservancy in Norway is based on the Nature Protection Act 1970. In the three decades since then, public attitudes to nature have become more nuanced and Indigenous rights more explicitly recognised. The challenge now is to reconcile nature conservation and Sámi rights. In order to deepen our insight into both problems and potential solutions we now consider some theoretical issues behind the problem. We start with basic attitudes towards nature.

\section{Nature philosophies}

Soupajärvi (2003) working in the Finnish part of Sapmi, defines relations to nature from three different perspectives: (1) traditional livelihoods like reindeer herding and agriculture, define nature as lived space; (2) industries, such as mining, large-scale forestry, and hydro-electric power generation, view nature as a resource; and (3) tourism in the postmodern society has cast nature in a role of experience. Tourists desire to visit 'wilderness' or 'unspoiled nature' (Page and Dowling, 2002). Reindeer herders and farmers from their perspective (1) seek the protection of nature from (2) and (3). The nature philosophies of farmers and reindeer herders are similar but their vantage points are different: the former has the farm as a focal point and sees forests and mountains as outfields, the latter do not make this distinction, having close relations to lands scattered over a wide area and used during each annual cycle (Schanche, 2004).

\section{Institutions and co-management}

The idea that all resource management regimes are embedded in a wider institutional context is a cornerstone of institutional policy analysis. These 
institutional arrangements operate at successive levels. Ostrom (2005) considers three institutional levels. Operational rules regulate everyday activities. For a national park the fixed rules facing all users by regulating access to and use of the landscape provide a typical example. Collective-choice rules regulate how decisions about operational rules are made: the process of establishing protection for a concrete piece of land is a collective-choice process. Finally, constitutional rules have the task of specifying governance conditions by stipulating where decisions are made and deciding on the level of freedom for the lower level rule sets. Constitutional rules determine the decisionmaking relations between major parties; in this case the sector authorities, the municipalities and the local and Indigenous residents. Ostrom (2005) also identifies an even deeper metaconstitutional level: in our context these are international political processes, for example, by IUCN, ILO or other UN agencies, which might impact on nature protection management in Norway.

The relationships between levels are important for institutional change. Changes in operational rules, for example, can only occur within a currently 'fixed' set of rules determined at a deeper level. In general, changes in deeper level rules are more difficult and more costly to accomplish (Ostrom, 2005, 55).We can expect actors in collective-choice processes to adopt level-shifting strategies to overcome the constraints of nested rule systems (Ostrom, 2005, 63).

In recent decades, there has been increased focus on transfer of control over natural resources from government agencies to user groups. Comanagement, or joint management of common resources, formulated as power sharing between the State and a communality of resource users, is seen as an alternative to top down government. Equity and efficiency are strong and overlapping arguments for co-management solutions. Power has been shared and co-management systems have evolved over time as outcomes of deliberate and mutual problem solving (Carlsson and Berkes, 2005). Co-management gains in these contexts have been abruptly halted by a new constellation of rules introduced by the nature protection agencies.

\section{From colonial conservation to Indigenous protected areas}

Colonialism was supported by the legal fiction of terra nullius (unoccupied land), expounded by the influential philosopher John Locke who argued that Indigenous peoples and nomads could neither acquire property rights to pasture lands, nor territorial sovereignty. Furthermore, the idea that knowledge of nature allows for the best possible use of resources became a driving force of imperialism and colonialism from the eighteenth century and of the ideology of 'developmentalism' in the twentieth century (Drayton, 2000). Science was recruited to widen the colonial endeavour (Adams, 2003).

Urban industrial development and prosperity in the western world produced new needs and philosophies. The western concept of wilderness as valuable was introduced, and nature was imagined as uninhabited and free of human influence (Langton, 1998). Concern to secure wilderness areas triggered the designation of the first national parks in the United States in the late-nineteenth century. As the wilderness ideology and the global economy expanded in the twentieth century, national parks were established across the globe, often with severe repercussions on Indigenous peoples.

A major shift in conservation approach is under way at the start of this century. Today the debate centres less on exclusion and more on how to reconcile the dual aims of protecting both peoples' rights and the conservation of biodiversity. The 1994 version of the IUCN Protected Area Management Categories recognised that Indigenous peoples may own and manage a protected area. This was done by extending the range of categories to include a new one: Category VI which is denoted as a Managed Resource Protected Area ${ }^{1}$ which puts biodiversity conservation and sustainable use on an equal footing. Subsequent guidelines have stressed the importance of Indigenous peoples' participation in conservation and the recognition of Indigenous peoples' rights to their lands and territories (Stolton and Oviedo, 2004). International networking has shifted the worldview of scientists and strengthened Indigenous peoples' position in conservation issues (CEESP and WCPA, 2006).

Sámi leaders and intellectuals have been an important part of the international networking (Minde, 2005). Within Norway, the Sámi Parliament has formulated its position and worked out a proposed set of guidelines for conservation planning in Sapmi and claimed that planning needs to be in line with international Indigenous peoples' law. A cornerstone of these proposals is that planning boards and management boards for conservation areas should have at least 50\% representation from Sámi organisations or rights holders (Sametinget, 2005). 


\section{Discussion}

The theoretical discussion shows that Indigenous and other rural residents have much in common in their nature philosophies, though there are differences in their relationships with the landscape. Co-existence has been possible historically and conflicts in modern times are resolved within the framework of the Planning and Building regime operated by the municipalities. The nature protection regime imposes other values and another discourse. In terms of institutional analysis, the environmental authorities have a predefined rule set which they have implemented locally without much deviation.

The Sámi boycott at Blåfjella-Skjækerfjella is the outcome of dissatisfaction at all three levels: reindeer herding needs have not been recognised in the collective-choice process; the operating rules hamper reindeer management and favour new recreation and tourist uses; and the constitutional level favours government managers and newly defined stakeholders to the point where Sámi have only a small minority representation. The boycott can be seen as a call on a meta-constitutional level by connecting to international instruments and international recognition of Indigenous rights in line with the Sámi Parliament proposal.

The current standoff at Blåfjella-Skjækerfjella suggests that the policy makers charged with nature protection in Nord Trøndelag have failed to recognise the potential of a co-operative management solution where all relevant parties have real influence. The reality here is that the authorities have made a compromise with the environmental sector and other local interests, to the detriment of Sámi reindeer herders.

The Norwegian government has not given a firm lead at the national policy level. Its ministers and officials have participated actively in international environmental and human rights forums but have been slow to incorporate the new insights into domestic policies with respect to national parks. It is symptomatic that the Nature Biodiversity Committee provided a short overview of the situation, but avoided any proposals on Sámi management models (NOU, 2004).

The boycott at Blåfjella-Skjækerfjella can be read as a sign that there are relationships to be put right in Nord Trøndelag. Communication has broken down between Sámi and the environmental sector. There are regional issues and national issues to be resolved. ${ }^{2}$ A multi level solution is needed to resolve conflicts between different uses within the park, to restore Sámi confidence in the potential of national parks, and to enable Norway as a nation to participate with integrity in the international community.

\section{ACKNOWLEDGEMENTS}

The author is grateful for the support of the following persons: Asbjørn Tingstad for supplying national park data, Marney Brosnan for map drawing, Michael Adams for help with international literature, Garth Cant, the issue editor group, and two anonymous referees for support and improvements to the manuscript, Randi Nymo and Juga Marie, Nymo Riseth for pleasant company on our joint 'down-under' travel.

\section{NOTES}

1. Areas containing predominantly unmodified natural systems, managed to ensure long-term protection and maintenance of biological diversity, while also providing a sustainable flow of natural products and services to meet community needs (Stolton and Oviedo, 2004).

2. On January 31, 2007, the Ministry of Environment and the Sámi Parliament signed an agreement admitting the Sámi particular consultation rights on all steps of the treatment of conservation cases in Sámi areas. The agreement does not include Sámi representation in management bodies etc.

\section{REFERENCES}

Adams, W.M., 2003: Nature and the colonial mind. In Adams, W.M. and Mulligan, M. (eds) Decolonizing Nature. Strategies for Conservation in a Post-colonial Era. Earthscan, London, 16-50.

Adams, M., 2005: Beyond Yellowstone? Conservation and Indigenous rights in Australia and Sweden. In Cant, G., Goodall, A. and Inns, J. (eds) Discourses and Silences: Indigenous Peoples, Risks and Resistance. Department of Geography, University of Canterbury, Christchurch, 127-138.

Adams, W.M. and Mulligan, M. (eds) 2003: Strategies for Conservation in a Post-colonial Era. Earthscan, London.

Baker, R., Davies, J. and Young, E. (eds) 2001: Working on Country: Contemporary Indigenous Management of Australia's Lands and Coastal Regions. Oxford University Press, Melbourne.

Berge, E., 2006: Protected areas and traditional commons: values and institutions. Norwegian Journal of Geography 60, 65-76.

Berkes, F., Colding, J. and Folke, C., 2003: Navigating Social-ecological Systems: Building Resilience for Complexity and Change. Cambridge University Press, Cambridge.

Bull, K.S., 2003: Samiske sedvaner som rettsgrunnlag for medbestemmelse? In Bjerkli, B. and Selle, P. (eds) Samer, Makt og Demokrati. Makt-og Demokratiutredningen. Gyldendal, Oslo, 202-218.

Bull, K.S., 2004: Reindriftens juridiske stilling i utbyggingssaker. In Vistnes, I., Nellemann, C. and Bull, K.S. (eds) Inngrep i reinbeiteland. Biologi, jus og strategier i utbyggingssaker. NINA Temahefte 26, NINA, Trondheim, 32-51.

Carlsson, L. and Berkes, F., 2005: Co-management: concepts and methodological implications. Journal of Environmental Management 75, 65-76.

CEESP and WCPA, 2006: Indigenous and Local Communities, Equity and Protected Areas. Retrieved 2 January, 2007 from $<$ http://www.iucn.org/themes/ceesp/Wkg_grp/TILCEPA/ TILCEPA.htm>.

Chatty, D., 1998: Enclosures and exclusions: conserving 
wildlife in pastoral areas of the Middle East. Anthropology Today 14, 2-7.

Drayton, R., 2000: Nature's Government: Science, Imperial Britain and the 'Improvement' of the World. Yale University Press, New Haven.

Fearnside, P.M., 2003: Conservation policy in Brazilian Amazonia: understanding the dilemmas. World Development 31, 757-779.

Folke, C., 2004: Traditional knowledge in socio-ecological systems. Ecology and Society 9, Retrieved 26 January 2007 from <http://www.ecologyandsociety.org/vol9/iss3/art7/>.

Hansen, L. and Olsen, B., 2004: Samenes Historie fram til 1750. Cappelen, Oslo.

Helander, E. and Mustonen, T. (eds) 2004: Snowscapes, Dreamscapes. Snowchange Book on Community Voices of Change. Tampere Polytechnic Publications, Tampere.

Hitchcock, R.K., 2002: 'We are the First People': Land, natural resources and identity in the Central Kalahari. Journal of Southern African Studies 28, 797-824.

IUCN [International Union for Conservation of Nature and Natural Resources], 1994: Guidelines for Protected Area Management Categories. IUCN Publications, Cambridge.

Jacoby, K., 2001: Crimes against Nature: Squatters, Poachers, Thieves, and the Hidden History of American Conservation. University of California Press, Berkeley.

Jystad, P.T., 2006: Vil ikke delta under nasjonalparkåpning. Reindriftsnytt 40(2), 36-37.

Jystad, P.T., 2007: Delt om reindrift og nasjonalparker. Reindriftsnytt 41, 28-31.

Langton, M., 1998: Burning Questions: Emerging Environmental Issues for Indigenous Peoples in northern Australia. Centre for Indigenous Natural and Cultural Resource Management, Northern Territory University, Darwin.

Lasko, K., 2005: Laponia II? The co-operative working group for Laponia's world heritage site. In Cant, G., Goodall, A. and Inns, J. (eds) Discourses and Silences: Indigenous Rights, Risks and Resistance. Department of Geography, University of Canterbury, Christchurch, 139-152.

Mazzullo, N., 2005: Environmental conservation and local interests in Finnish Lapland. Conservation and Society 3, 388-406.

Minde, H., 2005: The Alta case: from the local to the global and back again. In Cant, G., Goodall, A. and Inns, J. (eds) Discourses and Silences: Indigenous Rights, Risks and Resistance. Department of Geography, University of Canterbury, Christchurch, 13-34.

Moen, A., 1998: Nasjonalatlas for Norge: Vegetasjon. Statens Kartverk, Hønefoss.

NCA, 1970: The Nature Conservation Act. Retrieved 29 September, 2006 from <http://www.ub.uio.no/ujur/ulovdata/ lov-19700619-063-eng.pdf $>$.

Neuman, R.P., 1998: Imposing Wilderness: Struggles over Livelihood and Nature Preservation in Africa. University of California Press, Berkeley.

Nicholas, C., 2005: Who can protect the forest better? Pitching Orang Asli against professionals in protected area management in Peninsular Malaysia. International Symposium on Eco-Human Interactions in Tropical Forests. Kyoto University, Japan. Society of Tropical Ecology, Kyoto. Retrieved 2 March, 2007 from <http://www.coac.org.my/ codenavia/portals/coacv1/code/main/main_art.php?parentID $=11400226426398 \& \operatorname{artID}=11374532336034>$.

NOU, 1984: Om samenes rettsstilling. Case number 18 . Universitetsforlaget, Oslo, Bergen, Troms $\varnothing$.

NOU, 1986: Ny landsplan for nasjonalparker. Case number 13. Universitetsforlaget, Oslo, Bergen, Stavanger, Troms $\varnothing$.

NOU, 2004: Naturmangfoldloven. Case number 28. Universitetsforlaget, Oslo, Bergen, Stavanger, Troms $\varnothing$.
NTCC [North-Troendelag County Council], 2001: Community development through sustainable resource management in peripheral areas - process and demonstration. SafeinheritSafeguarding Our Heritage. North-Troendelag County Council.

Ostrom, E., 2005: Understanding Institutional Diversity. Princeton University Press, Princeton, New Jersey.

Page, S.J. and Dowling, R.K. 2002. Ecotourism. Pearson Education, Harlow, England.

Pawson, E. and Cant, G., 1992: Land rights in historical and contemporary context. Applied Geography 12(2), 95-108.

Poirier, R. and Ostergren, D., 2002: Evicting people from nature: Indigenous land rights and national parks in Australia, Russia and the United States. Natural Resources Journal 42, 331-352.

Riseth, J.Å., 2005: 'So the last shall be first, and the first last'? Sámi Reindeer Management vs. other land users in Mid-Scandinavia. In Cant, G., Goodall, A. and Inns, J. (eds) Discourses and Silences: Indigenous Rights, Risks and Resistance. Department of Geography, University of Canterbury, Christchurch, 35-55.

Sametinget, 2005. Retningslinjer for verneplanarbeid i Samiske områder. Sametinget, case number 13/05.

Schanche, A., 2004: Horizontal and vertical perceptions of Saami landscapes. In Jones, M. and Schanche, A. (eds) Landscape, Law and Customary Rights. Diedut 3, 1-10.

Sevatdal, H., 1998: Common property in Norway's rural areas. In Berge, E. and Stenseth, N.C. (eds) Law and the Governance of Renewable Resources. ICS Press, Oakland, California, 141-161.

Skjeggedal, T., Arnesen, T., Markhus, G. and Thingstad, P.G., 2004: Management strategies in forest landscapes in Norway. In Palang, H., Sooväli, H., Antrop, M. and Setten, G. (eds) European Rural Landscapes: Persistence and Change in a Globalising Environment. Kluwer, Dordrecht, 425-444.

Smardon, R.C. and Faust, B.B., 2006: Introduction: international policy in the biosphere reserves of Mexico's Yucatan peninsula. Landscape and Urban Planning 74, 160-192.

Soupajärvi, L., 2003. Competing industries and contested nature in Finnish Lapland after World War II. In Möller, S. and Pehkonen, S. (eds) Encountering the North. Cultural Geography, International Relations and Northern Landscapes. Ashgate, Aldershot, 203-220.

Stevens, S., 1997: Conservation through Cultural Survival: Indigenous Peoples and Protected Areas. Island Press, Washington DC.

St. meld., 1991-1992: Ny landsplan for nasjonalparker og andre større verneområder i Norge. Case number 62 . Miljøverndepartementet, Oslo.

Stolton, S. and Oviedio, G., 2004: Using the categories to support the needs and rights of traditional and indigenous peoples in protected areas. In Bishop, K., Dudley, N., Phillips, A. and Stolton, S. (eds) Speaking a Common Language. The Uses and Performance of the IUCN System of Management Categories for Protected Areas. Cardiff University, IUCN-The World Conservation Union and UNEP - World Conservation Monitoring Centre, Cardiff.

Vatn, A., 2005: Institutions and the Environment. Edward Elgar, Cheltenham, Northampton.

WCED [World Commission on Environment and Development], 1987: Our Common Future. Oxford University Press, Oxford. West, P.C. and Brechin, S.R. 1991: Resident Peoples and National Parks. The University of Arizona Press, Tucson.

Zachrisson, I., 1994: Archaeology and politics: Saami prehistory and history in central Scandinavia. Journal of European Archaeology 2, 361-368. 